\title{
KEEFEKTIFAN PEMBELAJARAN KONTEKSTUAL TERHADAP KESULITAN BELAJAR MATEMATIKA DAN KEMAMPUAN PENALARAN MATEMATIS SISWA
}

\author{
Faizal Fanany ${ }^{1}$, Isnani ${ }^{2}$, Ahmadi $^{3}$ \\ Universitas Pancasakti Tegal ${ }^{1,2,3}$ \\ faizal.fanany@gmail.com ${ }^{1}$, isnani.ups@gmail.com²
}

\begin{abstract}
ABSTRAK
Penelitian ini bertujuan untuk melihat keefektifan pembelajaran kontekstual terhadap kesulitan belajar dan kemampuan penalaran matematis siswa. Populasi pada penelitian ini adalah siswa kelas VIII semester I SMP Negeri 1 Dukuhturi Tahun Pelajaran 2018/2019. Pengambilan sampel dengan cluster random sampling. Sampel yang diambil sebanyak 3 kelas, yaitu kelas eksperimen, kelas kontrol dan kelas uji coba. Pengumpulan data menggunakan angket dan tes. Teknik analisis data yang digunakan uji proporsi, uji t satu pihak kanan, uji manova, dan uji $\tau^{2}$-Hotelling. Hasil penelitian menyatakan bahwa pembelajaran matematika yang diajar menggunakan pembelajaran kontekstual dapat melampaui target, pembelajaran kontekstual lebih baik daripada pembelajaran konvensional terhadap kesulitan belajar, dan terhadap kemampuan penalaran matematis siswa, ada perbedaan yang signifikan kesulitan belajar dan kemampuan penalaran matematis antara siswa yang diajar menggunakan pembelajaran kontekstual dengan siswa yang diajar menggunakan pembelajaran konvensional, pembelajaran kontekstual lebih baik daripada pembelajaran konvensional terhadap kesulitan belajar dan kemampuan penalaran matematis siswa.
\end{abstract}

Kata kunci: keefektifan, pembelajaran kontekstual, kesulitan belajar matematika, kemampuan penalaran matematis

\begin{abstract}
This study aims to look at the effectiveness of contextual learning on learning difficulties and students' mathematical reasoning abilities. The population in this study were students of class VIII in the first semester of SMP Negeri 1 Dukuhturi Academic Year 2018/2019. Sampling by cluster random sampling. The samples taken were 3 classes, namely the experimental class, the control class and the trial class. Data collection uses questionnaires and tests. The data analysis technique used is the proportion test, the right one $t$ test, the manova test, and the $2^{\wedge} 2$-Hotelling test. The results of the study state that mathematics learning taught using contextual learning can exceed the target, contextual learning is better than conventional learning on learning difficulties, and on students' mathematical reasoning abilities, there are significant differences in learning difficulties and mathematical reasoning abilities between students taught using contextual learning with students taught using conventional learning, contextual learning is better than conventional learning on learning difficulties and students' mathematical reasoning abilities.
\end{abstract}

Keywords : effectiveness, contextual learning, difficulty learning mathematics, mathematical reasoning abilities. 


\section{PENDAHULUAN}

Matematika merupakan salah satu bidang ilmu pengetahuan yang didapatkan siswa di dunia pendidikan dari tingkat dasar sampai tingkat paling atas. Matematika adalah pembelajaran yang sangat penting dan berguna bagi manusia karena secara langsung diterapkan dalam kehidupan sehari-hari. Pada hakikatnya, belajar matematika merupakan proses melatih otak untuk dapat berpikir logis, teratur, berkesinambungan dan menyatakan bukti-bukti kuat dalam setiap pernyataan yang diucapkan (Dewi, Isnani, dan Ahmadi, 2019). Namun, banyak di antara siswa beranggapan bahwa matematika adalah pembelajaran yang sulit (Hidayati, Isnani, dan Susongko, 2017). Menurut Nisa (2011:13) kesulitan belajar matematika dapat dikatakan sebagai suatu kondisi dalam pembelajaran yang ditandai dengan adanya hambatan-hambatan tertentu dalam mencapai hasil belajar matematika sesuai dengan potensi atau kemampuan yang dimiliki oleh siswa.

Salah satu yang ditekankan dalam pembelajaran matematika yaitu kemampuan penalaran matematis. Sumartini (2015:3-4) mengatakan bahwa kemampuan penalaran matematis adalah kemampuan dalam menyimpulkan dan membuktikan suatu pernyataan, membangun gagasan baru, sampai pada menyelesaikan masalahmasalah dalam matematika. Kemampuan penalaran matematis harus selalu dibiasakan dan dikembangkan dalam setiap pembelajaran matematika. Lebih khusus lagi, kemampuan penalaran matematis yang perlu dilatih pada siswa yaitu berupa menarik kesimpulan logis; memberikan penjelasan dengan model, fakta, sifat-sifat, dan hubungan; memperkirakan jawaban dan proses solusi; menyusun argumen yang valid; dan menyusun pembuktian langsung, tidak langung, dan menggunakan induksi matematika.

Berdasarkan hasil wawancara dengan guru matematika kelas VIII di SMPN 1 Dukuhturi ditemukan bahwa kemampuan penalaran matematis siswa masih tergolong rendah sehingga hasil belajar matematika yang dicapai siswa juga masih rendah. Hal ini ditunjukkan dari rata-rata nilai matematika yang masih di bawah nilai KKM yaitu 74, secara klasikal hanya mencapai $30 \%$.

Melihat kondisi di atas, sangat terlihat bahwa persepsi siswa pada pembelajaran matematika dapat berpengaruh pada prestasi belajar. Selain itu, belum pernah dilakukan tes untuk mengukur kemampuan penalaran matematis siswa, serta kesulitan belajar matematika, sehingga siswa kurang terampil dan masih kesulitan dalam pemecahan masalah yang berkaitan dengan pelajaran matematika.

Kesulitan dalam mempelajari matematika terbagi atas 2 faktor, faktor internal antara lain; kelemahan secara mental; kelemahan secara emosional; minat; dan kelemahan pengetahuan dan keterampilan. Sedangkan faktor eksternal, antara lain: fasilitas sekolah; relasi guru dengan peserta didik dan metode mengajar guru; serta kelemahan yang terdapat dalam kondisi rumah tangga.

Pemilihan strategi pembelajaran yang tepat dapat berpengaruh terhadap prestasi belajar matematika peserta didik. Strategi pembelajaran yang sebaiknya diterapkan adalah strategi pembelajaran yang memberikan kesempatan kepada peserta didik untuk mengkonsumsi pengetahuannya sendiri sehingga peserta didik lebih mudah untuk memahami konsep yang diajarkan (Safitri, Wahyuningsih, dan Ahmadi, 2019). Sementara itu model pembelajaran yang digunakan oleh guru masih berupa model pembelajaran konvensional, model pembelajaran ini hanya disajikan secara monoton oleh guru. Guru yang berperan aktif dalam pembelajaran, sementara 
siswa hanya dituntut untuk mendengarkan, mencatat bahkan menghapal saja sehingga tidak mendorong keaktifan siswa dalam pembelajaran. Hal ini yang menyebabkan siswa malas berpikir dan timbul perasaan bosan dalam mengikuti pembelajaran. Akibatnya, hasil belajar matematika siswa kurang maksimal dan tidak memenuhi Kriteria Ketuntasan Minimal (KKM) yang ditetapkan oleh sekolah.

Salah satu alternatif untuk mengatasi permasalahan di atas adalah penggunaan model pembelajaran, pemilihan model pembelajaran yang dapat memicu siswa untuk berperan aktif dan dapat mengembangkan potensi pengetahuannya dalam kegiatan pembelajaran yaitu dengan penggunaan model pembelajaran Kontekstual. Menurut Lestari dan Ridwan (2015:38) pembelajaran kontekstual juga dapat dipandang sebagai suatu model pembelajaran yang memungkinkan terjadinya proses belajar yang memungkinkan siswa untuk menerapkan pemahaman serta kemampuan akademiknya dalam berbagai variasi konteks, baik di dalam maupun di luar kelas guna menyelesaikan permasalahan nyata atau yang disimulasikan secara individual maupun kelompok.

Penelitian yang pernah dilakukan Amin (2017) di Madrasah Aliyah Brebes 01 menunjukkan bahwa model pembelajaran kontekstual terbukti lebih baik daripada pembelajaran konvensional. Juga penelitian Syahbana (2012) menunjukkan bahwa penggunaan pendekatan kontekstual dapat meningkatkan kemampuan berpikir kritis matematis siswa SMP.

Penelitian ini bertujuan untuk melihat pembelajaran matematika yang diajar menggunakan pembelajaran kontekstual dapat melampaui target, pembelajaran kontekstual lebih baik daripada pembelajaran konvensional terhadap kesulitan belajar, dan terhadap kemampuan penalaran matematis siswa, ada perbedaan yang signifikan kesulitan belajar dan kemampuan penalaran matematis antara siswa yang diajar menggunakan pembelajaran kontekstual dengan siswa yang diajar menggunakan pembelajaran konvensional, pembelajaran kontekstual lebih baik daripada pembelajaran konvensional terhadap kesulitan belajar dan kemampuan penalaran matematis siswa..

\section{METODE}

Penelitian ini menggunakan pendekatan kuantitatif dan termasuk jenis penelitian eksperimen. Kelas eksperimen dalam penelitian ini adalah yang diberikan perlakuan dengan menggunakan model pembelajaran kontekstual, sedangkan kelas kontrol dalam penelitian ini adalah kelas yang menggunakan model pembelajaran konvensional. Populasi dalam penelitian ini adalah seluruh siswa kelas VIII yang berjumlah 280 siswa. Sampel dalam penelitian ini berjumlah 92 peserta didik dimana kelas VIIIA sebagai kelas eksperimen, kelas VIIIB sebagai kelas kontrol, dan kelas VIIID sebagai kelas ujicoba. Pengambilan sampel menggunakan teknik Cluster Random Sampling. Teknik pengumpulan data yang digunakan adalah pemberian angket dan tes.

Instrumen penelitian ini adalah angket dan tes. Angket digunakan untuk memperoleh data kesulitan belajar matematika siswa, sedangkan tes digunakan dalam bentuk uraian untuk mendapatkan nilai kemampuan penalaran matematis siswa setelah mengikuti materi pelajaran persamaan linear dua variabel. Teknik analisis data yang digunakan adalah (1) Uji kesetaraan sampel sebelum penelitian meliputi uji normalitas, uji homogenitas, dan uji kesetaraan sampel. (2) Uji prasyarat 
hipotesis meliputi uji normalitas dan homogenitas data prestasi belajar matematika. (3) uji hipotesis meliputi uji proporsi, uji t satu pihak kanan, uji manova, dan uji $\tau^{2}$ Hotelling.

\section{HASIL DAN PEMBAHASAN}

Uji kesetaraan sampel meliputi melakukan uji normalitas dan uji homogenitas, dan uji kesetaraan sampel. Data yang diuji menggunakan data Penilaian Tengah Semester I tahun 2018.

Berikut hasil uji normalitas untuk kesetaraan sampel :

Tabel 1. Uji normalitas untuk kesetaraan sampel

\begin{tabular}{cccccc}
\hline No & $\mathrm{L}_{\text {hitung }}$ & $\mathrm{L}_{\text {tabel }}$ & $\alpha$ & Interpretasi & Kesimpulan \\
\hline 1 & 0,073 & 0,092 & 0,05 & Normal & $\mathrm{H}_{0}$ diterima \\
\hline
\end{tabular}

Dengan daerah kriteria tolak $\mathrm{H}_{0}$ jika $L_{0}$ yang diperoleh melebihi $L_{\text {tabel }}$, maka dalam hal lain $\mathrm{H}_{0}$ diterima dengan taraf signifikan 5\%. Berdasarkan tabel 1, didapat bahwa $\mathrm{H}_{0}$ diterima artinya sampel berasal dari populasi yang berdistribusi normal.

Berikut hasil uji homogenitas untuk kesetaraan sampel :

Tabel 2. Uji homogenitas untuk kesetaraan sampel

\begin{tabular}{cccc}
\hline No & $\chi^{2}{ }_{\text {hitung }}$ & $\chi^{2}{ }_{\text {tabel }}$ & Kesimpulan \\
\hline 1 & 2,077 & 5,991 & Homogen \\
\hline
\end{tabular}

Dengan daerah kriteria tolak $\mathrm{H}_{0}$ jika $\chi^{2}$ yang diperoleh melebihi $\chi^{2}$ tabel. Karena $\chi_{\text {hitung }}^{2}<\chi_{\text {tabel }}^{2}$ maka dalam hal lain $\mathrm{H}_{0}$ diterima dengan taraf signifikan $5 \%$. Berdasarkan tabel 2, didapat bahwa $\mathrm{H}_{0}$ diterima artinya sampel berasal dari populasiyang mempunyai keragaman homogen.

Karena sampel berasal dari populasi yang berdistribusi normal dan sampel berasal dari populasi yang mempunyai keragaman homogen maka dilakukan uji kesetaraan sampel. Berikut hasil uji kesetaraan sampel :

Tabel 3. Uji kesetaraan sampel

\begin{tabular}{lccccc}
\hline \multicolumn{1}{c}{ Sumber Variasi } & JK & Db & RK & F hit & F tabel \\
\hline Kelompok (K) & 288.401 & 2 & 144.201 & & \\
Dalam (D) & 23426.512 & 89 & 263.219 & 0.548 & 3.098 \\
Total (T) & 23714.913 & 91 & & & \\
\hline Kesimpulan & SETARA & \multicolumn{5}{c}{ karena $\mathrm{F}_{\text {tabel }}>\mathrm{F}_{\text {hitung }}$} \\
\hline
\end{tabular}

Hipotesis yang digunakan uji kesetaraan sampel adalah :

$\mathrm{H}_{0}$ : Tidak ada perbedaan untuk setiap kelas eksperimen, kelas kontrol, dan kelas uji coba (sampel setara).

$\mathrm{H}_{\mathrm{a}}$ : Paling sedikit ada satu yang berbeda untuk setiap kelas eksperimen, kelas kontrol, dan kelas uji coba (sampel setara).

Dengan daerah kriteria jika $\mathrm{F}_{\text {hitung }} \leq \mathrm{F}_{\text {tabel }}$, maka $\mathrm{H}_{0}$ diterima dengan taraf signifikan $5 \%$. Berdasarkan tabel 3 , didapat bahwa $\mathrm{H}_{0}$ diterima artinya tidak ada perbedaan untuk setiap kelas eksperimen, kelas kontrol, dan kelas uji coba. 
Sebelum menguji hipotesis, terlebih dahulu menguji uji prasyarat hipotesis yang terdiri dari uji normalitas dan uji homogenitas. Uji prasyarat ini menggunakan data prestasi belajar matematika.

Berikut hasil uji normalitas untuk uji prasyarat hipotesis :

Tabel 4. Uji normalitas untuk uji prasyarat hipotesis

\begin{tabular}{|c|c|c|c|c|c|}
\hline No & Variabel & $\mathrm{N}$ & $\mathrm{L}_{\text {hitung }}$ & $\mathrm{L}_{\text {tabel }}$ & Kesimpulan \\
\hline 1 & $\begin{array}{c}\text { Kelas } \\
\text { Eksperimen }\end{array}$ & 30 & 0,116 & 0,161 & No \\
\hline 2 & Kelas Kontrol & 31 & 0,120 & 0,159 & Normal \\
\hline
\end{tabular}

Dengan daerah kriteria tolak $\mathrm{H}_{0}$ jika $L_{0}$ yang diperoleh melebihi $L_{\text {tabel }}$, maka dalam hal lain $\mathrm{H}_{0}$ diterima dengan taraf signifikan 5\%. Berdasarkan tabel 4 , didapat bahwa $\mathrm{H}_{0}$ diterima artinya sampel berasal dari populasi yang berdistribusi normal baik kelas eksperimen maupun kelas kontrol.

Berikut hasil uji homogenitas untuk uji prasyarat hipotesis :

Tabel 5. Uji homogenitas untuk uji prasyarat hipotesis

\begin{tabular}{cccc}
\hline No & $\chi^{2}{ }_{\text {hitung }}$ & $\chi^{2}{ }_{\text {tabel }}$ & Kesimpulan \\
\hline 1 & 0,248 & 3,841 & Homogen \\
\hline
\end{tabular}

Dengan daerah kriteria tolak $\mathrm{H}_{0}$ jika $\chi^{2}$ yang diperoleh melebihi $\chi_{\text {tabel, }}^{2}$ maka dalam hal lain $\mathrm{H}_{0}$ diterima dengan taraf signifikan $5 \%$ karena $\chi_{\text {hitung }}^{2} \chi_{\text {tabel }}^{2}$. Berdasarkan tabel 5, didapat bahwa $\mathrm{H}_{0}$ diterima artinya sampel berasal dari populasi yang mempunyai keragaman homogen.

Uji Proporsi adalah uji untuk mengetahui efektivitas suatu pembelajaran dalam memenuhi target yang ditentukan (Gaspersz, 1995). Adapun Hasil uji proporsi dalam penelitian ini adalah :

Tabel 6. Uji proporsi

\begin{tabular}{ccccc}
\hline No & Variabel & $Z_{\text {hitung }}$ & $Z_{\text {tabel }}$ & Kesimpulan \\
\hline 1 & $\begin{array}{c}\text { Kelas } \\
\text { Ekperimen }\end{array}$ & 2,644 & 0,136 & Melampai 31\% \\
\hline
\end{tabular}

Hipotesis yang digunakan untuk uji proporsi adalah :

$\mathrm{H}_{0}: \pi \leq 31 \%$, artinya pembelajaran matematika yang diajar menggunakan pembelajaran kontekstual tidak dapat melampaui target.

$\mathrm{H}_{\mathrm{a}}: \pi>31 \%$, artinya pembelajaran matematika yang diajar menggunakan pembelajaran kontekstual dapat melampaui target.

$\mathrm{H}_{0}$ diterima apabila $Z<Z_{0,5-\alpha}$ dan $\mathrm{H}_{0}$ ditolak apabila $Z \geq Z_{0,5-\alpha}$ dan taraf signifikan $5 \%$.

Pembelajaran matematika yang diajar menggunakan model pembelajaran kontekstual dapat melampaui target, hal ini karena dalam pembelajaran kontekstual siswa diberi kebebasan dalam membangun ide dan memberikan penegasan pada materi yang telah dipelajari, serta siswa dilatih bekerja sama dalam mencapai tujuan pembelajaran dan aktif membantu bahkan diharuskan memotivasi semangat kelompoknya untuk berhasil bersama. 
Berdasarkan tabel 6, dapat disimpulkan bahwa $\mathrm{H}_{0}$ ditolak artinya pembelajaran matematika yang diajar menggunakan pembelajaran kontekstual melampaui target, yaitu melampaui $31 \%$ dari siswa kelas eksperimen yang dapat mencapai nilai KKM.

Uji t satu pihak kanan digunakan untuk mengetahui (1) Pembelajaran kontekstual lebih baik daripada pembelajaran konvensional terhadap kesulitan belajar matematika. (2) Pembelajaran kontekstual lebih baik daripada pembelajaran konvensional terhadap kemampuan penalaran matematis.

Berikut hasil uji t satu pihak kanan untuk model pembelajaran kontekstual lebih baik dari pada model pembelajaran konvensional terhadap kesulitan belajar matematika siswa.

Tabel 7. Uji t satu pihak kanan

\begin{tabular}{cccc}
\hline No & $\mathrm{T}_{\text {hitung }}$ & $\mathrm{T}_{\text {tabel }}$ & Kesimpulan \\
\hline 1 & 3,952 & 2,001 & $\mathrm{H}_{0}$ ditolak \\
\hline
\end{tabular}

Hipotesis yang digunakan untuk uji t satu pihak kanan adalah:

$\mathrm{H}_{0}$ : Pembelajaran kontekstual tidak lebih baik daripada pembelajaran konvensional terhadap kesulitan belajar matematika.

$\mathrm{H}_{\mathrm{a}}$ : Pembelajaran kontekstual lebih baik daripada pembelajaran konvensional terhadap kesulitan belajar matematika.

$\mathrm{H}_{0}$ diterima jika $\mathrm{t}_{\text {hitung }}<\mathrm{t}_{\text {tabel }}$ dan taraf signifikan $5 \%$.

Berdasarkan hasil penelitian kesulitan belajar matematika siswa yang diajar dengan pembelajaran kontekstual menunjukkan hasil yang positif, hal ini karena dalam pembelajaran kontekstual siswa diajarkan bekerjasama dalam suatu kelompok, siswa aktif berperan sebagai tutor sebaya, peningkatan kemampuan dalam berpendapat, dan meningkatkan kecakapan individu. Dari penelitian Nisa (2011), disebutkan bahwa kesulitan belajar yang dialami siswa beraneka ragam, tidak sama apa yang dialami oleh setiap siswa. Kesulitan belajar siswa di antaranya: kesulitan belajar dengan latar belakang kebiasaan belajar yang salah, kesulitan belajar dengan latar belakang kurangnya motivasi dan minat belajar, kesulitan belajar dengan latar belakang kurang menguasai keterampilan berhitung. Dengan penerapan pembelajaran kontekstual, kesulitan belajar matematika siswa lebih sedikit daripada penerapan pembelajaran konvensional, hal ini dapat dilihat dari hasil angket yang diberikan kepada siswa lebih sedikit yang mengalami kesulitan belajar matematika yang sebelumnya lebih banyak.

Berdasarkan tabel 7 , didapat bahwa $\mathrm{H}_{0}$ ditolak artinya pembelajaran kontekstual lebih baik daripada pembelajaran konvensional terhadap kesulitan belajar matematika.

Berikut hasil uji t satu pihak kanan untuk pembelajaran kontekstual lebih baik daripada pembelajaran konvensional terhadap kemampuan penalaran matematis siswa.

Tabel 8. Uji t satu pihak kanan

\begin{tabular}{cccc}
\hline No & $\mathrm{T}_{\text {hitung }}$ & $\mathrm{T}_{\text {tabel }}$ & Kesimpulan \\
\hline 1 & 4,196 & 2,001 & $\mathrm{H}_{0}$ ditolak \\
\hline
\end{tabular}


Hipotesis yang digunakan untuk uji t satu pihak kanan adalah:

$\mathrm{H}_{0}$ : Pembelajaran kontekstual tidak lebih baik daripada pembelajaran konvensional terhadap kemampuan penalaran matematis siswa.

$\mathrm{H}_{\mathrm{a}}$ : Pembelajaran kontekstual lebih baik daripada pembelajaran konvensional terhadap kemampuan penalaran matematis siswa.

$\mathrm{H}_{0}$ diterima jika $\mathrm{t}_{\text {hitung }}>\mathrm{t}_{\text {tabel }}$ dan taraf signifikan $5 \%$.

Berdasarkan hasil penelitian kemampuan penalaran matematis siswa yang diajar dengan pembelajaran kontekstual menujukkan nilai lebih tinggi daripada yang diajar dengan pembelajaran konvensional, hal ini karena dalam pembelajaran kontekstual siswa terlibat dalam proses pembelajaran, dimana siswa bebas untuk membangun gagasannya sehingga meningkatkan kreativitas dalam memecahkan masalah matematika yang artinya kemampuan penalaran matematisnya lebih tinggi, serta siswa dilatih bekerja sama dalam mencapai tujuan pembelajaran dan aktif membantu bahkan diharuskan memotivasi semangat kelompoknya agar berhasil bersama. Sehingga, selain siswa diberikan materi oleh guru, siswa yang belum paham atau bingung tentang contoh soal dapat dijelaskan oleh teman sekelompoknya sampai paham. Dengan adanya sistem diskusi maka akan terbetuk masyarakat belajar yang memungkinkan siswa saling membantu, bagi siswa yang merasa mampu akan memberikan masukan yang berarti bagi teman kelompoknya pada saat melakukan diskusi maupun mengemukakan pendapat

Berdasarkan tabel 8, didapat bahwa $\mathrm{H}_{0}$ ditolak artinya pembelajaran kontekstual lebih baik daripada pembelajaran konvensional terhadap kemampuan penalaran matematis siswa.

Uji Manova-One Way digunakan untuk mengetahui ada tidaknya perbedaan kesulitan belajar matematika dan kemampuan penalaran matematis yang diajar menggunakan pembelajaran kontekstual dengan yang diajar menggunakan pembelajaran konvensional.

Tabel 9. Uji Manova

\begin{tabular}{cccc}
\hline No & $\lambda_{\text {hitung }}$ & $\lambda_{\text {tabel }}$ & Kesimpulan \\
\hline 1 & 0,700 & 0,903 & $\mathrm{H}_{0}$ ditolak \\
\hline
\end{tabular}

Hipotesis yang digunakan untuk uji manova adalah :

$\mathrm{H}_{0}$ : Tidak ada perbedaan yang signifikan setelah diajar dengan menggunakan pembelajaran kontekstual dan pembelajaran konvensional terhadap kesulitan belajar matematika dan kemampuan penalaran matematis siswa.

$\mathrm{H}_{\mathrm{a}}$ : Ada perbedaan yang signifikan setelah diajar dengan menggunakan pembelajaran kontekstual dan pembelajaran konvensional terhadap kesulitan belajar matematika dan kemampuan penalaran matematis siswa

$\mathrm{H}_{0}$ diterima jika $\lambda_{\text {hitung }}<\lambda_{\text {tabel }}$ dan taraf signifikan $5 \%$.

Berdasarkan hasil penelitian terdapat perbedaan kesulitan belajar matematika dan kemampuan penalaran matematis siswa yang diajar dengan pembelajaran kontekstual dengan pembelajaran konvensional, hal ini karena perbedaan tahapan pembelajaran pada setiap model pembelajaran yang diterapkan. Pembelajaran kontekstual bertujuan meningkatkan aktivitas belajar siswa pada sesi diskusi agar 
kesulitan-kesulitan dalam belajar matematika dapat terminimalisir dengan adanya kerjasama kelompok belajar, saling berbagi pengetahuan dan bertukar ide kepada teman kelompoknya, dan meningkatkan kemampuan penalaran matematis melalui kreativitas siswa dalam membangun gagasan dan tambahan pengetahuan dari teman satu kelompoknya pada saat sesi diskusi. Siswa yang diajar dengan model pembelajaran kontekstual diberikan kebebasan untuk mengembangkan pengetahuan yang telah dimiliki atas apa yang sudah dipelajari. Siswa dilatih bekerja sama dalam mencapai tujuan pembelajaran, siswa berperan aktif sebagai tutor sebaya, peningkatan kemampuan dalam berpendapat. Hal ini yang mengakibatkan perbedaan kesulitan belajar matematika dan kemampuan penalaran matematis siswa.

Berdasarkan tabel 9, didapat bahwa $\mathrm{H}_{0}$ ditolak artinya ada perbedaan yang signifikan setelah diajar dengan menggunakan pembelajaran kontekstual dan pembelajaran konvensional terhadap kesulitan belajar matematika dan kemampuan penalaran matematis siswa.

Uji $\tau^{2}$-Hotelling digunakan untuk menganalisis kesulitan belajar matematika dan kemampuan penalaran matematika siswa yang diajar menggunakan pembelajaran kontekstual lebih baik daripada siswa yang diajar menggunakan pembelajaran konvensional.

Tabel 10. Uji $\tau^{2}$-Hotelling

\begin{tabular}{cccc}
\hline No & $\mathrm{F}_{\text {hitung }}$ & $\mathrm{F}_{\text {tabel }}$ & Kesimpulan \\
\hline 1 & 12,414 & 3,153 & $\mathrm{H}_{0}$ ditolak \\
\hline
\end{tabular}

Hipotesis yang digunakan untuk uji $\tau^{2}$-Hotelling adalah :

$\mathrm{H}_{\mathrm{o}}$ : Pembelajaran kontekstual tidak lebih baik digunakan daripada pembelajaran konvensional terhadap kesulitan belajar matematika dan kemampuan penalaran matematis siswa.

$\mathrm{H}_{\mathrm{a}}$ : Pembelajaran kontekstual lebih baik digunakan daripada pembelajaran konvensional terhadap kesulitan belajar matematika dan kemampuan penalaran matematis siswa.

$\mathrm{H}_{0}$ diterima jika $\mathrm{F}_{\text {hitung }}<\mathrm{F}_{\text {tabel }}$ dan taraf signifikan 5\%. Hasil perhitungan dengan menggunakan uji $\tau^{2}$ - Hotelling diperoleh $F_{\text {hitung }}=12,414$.

Berdasarkan hasil penelitian kesulitan belajar matematika dan kemampuan penalaran matematis antara kelas yang diajar pembelajaran kontekstual lebih tinggi daripada kelas yang diajar dengan pembelajaran konvensional. Hal ini karena siswa yang diajar dengan model pembelajaran kontekstual diberikan kebebasan untuk mengembangkan pengetahuan yang dimiliki atas apa yang telah dipelajari, siswa dilatih untuk lebih aktif dan bekerja sama dalam mencapai tujuan pembelajaran, peningkatan kemampuan dalam berpendapat, dan meningkatkan kecakapan individu. Hal ini yang mengakibatkan kesulitan belajar matematika dan kemampuan penalaran matematis siswa yang diajar dengan pembelajaran kontekstual lebih baik daripada pembelajaran konvensional.

Berdasarkan tabel 10, didapat bahwa $\mathrm{H}_{0}$ ditolak artinya pembelajaran kontekstual lebih baik digunakan daripada pembelajaran konvensional terhadap kesulitan belajar matematika dan kemampuan penalaran matematis siswa. 
Dengan demikian pembelajaran kontekstual efektif diterapkan dalam pembelajaran matematika khususnya mengatasi kesulitan belajar matematika dan kemampuan penalaran matematis siswa. Seperti halnya penelitian-penelitian lainnya, misalnya Syahbana (2012), Suhartini, dkk (2016), Suwanjal (2016) dan Amin (2017) yang telah menerapkan pembelajaran kontekstual, selalu diperoleh bahwa pembelajaran kontekstual sangat membantu dalam pembelajaran matematika.

\section{SIMPULAN}

Berdasarkan hasil penelitian dan pengolahan data pada keseluruhan tahapan penelitian dengan mengacu pada rumusan masalah yang dikemukakan pada pendahuluan, maka dapat diambil simpulan bahwa : (1) pembelajaran matematika yang diajar menggunakan pembelajaran kontekstual dapat melampaui target, (2) pembelajaran kontekstual lebih baik daripada pembelajaran konvensional terhadap kesulitan belajar matematika siswa, (3) pembelajaran kontekstual lebih baik dari pada pembelajaran konvesional terhadap kemampuan penalaran matematis siswa, (4) ada perbedaan yang signifikan kesulitan belajar matematika dan kemampuan penalaran matematis antara siswa yang diajar menggunakan pembelajaran kontekstual dengan siswa yang diajar menggunakan pembelajaran konvensional, dan (5) pembelajaran kontekstual lebih baik daripada pembelajaran konvensional terhadap kesulitan belajar matematika dan kemampuan penalaran matematis siswa.

\section{DAFTAR PUSTAKA}

Amin, Zaqiin. 2017. Keefektifan Model Pembelajaran Contextual Teaching and Learning Berbantu Alat Peraga Terhadap Prestasi Belajar Matematika. Skripsi tidak diterbitkan. Tegal: Universitas Pancasakti Tegal.

Dewi, A. S., Isnani, I., dan Ahmadi, A. 2019. Keefektifan Model Pembelajaran STAD Berbantuan Media Pembelajaran Terhadap Sikap dan Kemampuan Pemecahan Masalah Matematika. JIPMat, Vol. 4(1) : 7-11. Tersedia : http://journal.upgris.ac.id/index.php/JIPMat/article/view/3509/pdf

Gaspersz, Vincent. 1995. Teknik Analisis dalam Penelitian Percobaan. Bandung : Tarsito.

Hidayati, F., Isnani, I., dan Susongko, P. 2017. Pengaruh Persepsi Peserta Didik pada Pembelajaran Matematika Terhadap Prestasi Belajar Matematika di Sekolah Menengah Pertama. JPMP (Jurnal Pendidikan MIPA Pancasakti), Vol. 1(1) : 11-18. Tersedia : http://e-journal.upstegal.ac.id/index.php/jpmp/article/view/ $783 / 660$

Lestari, Karunia Eka dan Ridwan, Yudhanegara Mokhammad. 2015. Penelitian Pendidikan Matematika. Bandung: PT Refika Aditama.

Nisa, K. 2011. Analisis Kesulitan Belajar Matematika pada Peserta Didik Kelas VIII Semester II Pokok Bahasan Panjang Garis Singgung Persekutuan Dua Lingkaran MTs Negeri Bonang Tahun Pelajaran 2010/2011. Disertasi tidak diterbitkan. Semarang : IAIN Walisongo.

Safitri, D. A. N., Wahyuningsih, E. D., dan Ahmadi. 2019. Eksperimentasi Strategi Pembelajaran Heuristik Vee Terhadap Prestasi Belajar Matematika Ditinjau dari Kemampuan Komunikasi Matematis. Integral (Jurnal Penelitian Pendidikan Matematika), Vol. 1(2) : 109-114. 
Tersedia : http://integral.upstegal.ac.id/index.php/jppm/index

Suhartini, I., Syahputra, E., dan Surya, E. 2016. Pengaruh Pembelajaran Kontekstual Terhadap Kemampuan Pemecahan Masalah Matematik dan Kemandirian Belajar Siswa di MTs Miftahussalam Medan. Paradikma, Vol. 9(3) : 62-71.

Sumartini, T. S. 2015. Peningkatan Kemampuan Penalaran Matematis Siswa Melalui Pembelajaran Berbasis Masalah. Mosharafa, Vol. 5(1) : 1-10.

Suwanjal, Usep. 2016. Pengaruh Penerapan Pendekatan Kontekstual Terhadap Kemampuan Berpikir Kritis Matematis Siswa SMP. Aksioma, Vol. 5(1) : 6167. Tersedia : http://ojs.fkip.ummetro.ac.id/index.php/matematika/article/view/ 466/415

Syahbana, Ali. 2012. Peningkatan Kemampuan Berpikir Kritis Matematis Siswa SMP Melalui Pendekatan Contextual Teaching And Learning. Edumatica, Vol. 2(1) : 45-57. 